IRSH 6I (2016), Special Issue, pp. I 87-2 I I doi:I0.10I7/So0208590 I6000407 (C) 2016 Internationaal Instituut voor Sociale Geschiedenis

\title{
The Role of Unfree Labour in Capitalist Development: Spain and Its Empire, Nineteenth to the Twenty-First Centuries*
}

\author{
FERNANDO MENDIOLA \\ Department of Economics, Public University of Navarre \\ Campus Arrosadia, Edificio Departamental Los Madroños, \\ 3 I006 Iruñea-Pamplona, Spain
}

E-mail: fernando.mendiola@unavarra.es

\begin{abstract}
This article contributes to the debate on the persistence of forced labour within capitalist development. It focuses on Spain, which has been deeply rooted in the global economy, firstly as a colonial metropolis, and later as part of the European Union. In the first place, I analyse the different modalities of unfree labour that are included in the taxonomy established by the Global Collaboratory on the History of Labour Relations, taking into account the different political regimes in which they are inserted. Therefore, the legal framework regarding unfree labour is analysed for four different political contexts: liberal revolution with colonial empire (I 8 I 2-I 874); liberal parliamentarism with colonial empire (1874-1936); civil war and fascist dictatorship, with decolonization (1936-1975); and parliamentary democracy within globalization (1975-2014). The article goes on to deal with the importance of the main economic reasons driving the demand for forced labour: relative labour shortage and the search for increasing profits. In the conclusion, and taking the Spanish case as a basis, I suggest a series of challenges for furthering the global debate on the role of forced labour under capitalism.
\end{abstract}

\section{INTRODUCTION}

Forced labour is still an important problem today, not only in developing countries, but also in developed ones, as recent reports by the ILO point out. ${ }^{\mathrm{I}}$ As a result, economic debate on unfree labour is open, and much

* The article is part of the research project "Crime Control in Modern Spain: Security Discourses, Punitive Institutions and Emergency Practices” (HAR2013-4062 I-P), directed by Pedro Oliver Olmo (Universidad de Castilla-La Mancha) and funded by the Spanish Ministry of Science and Innovation. I want to thank the anonymous referees and the editors of this Special Issue for their helpful comments and Robert Curwen for his help with the translation into English.

I. ILO, The Cost of Coercion (Geneva, 2009); idem, Profits and Poverty: The Economics of Forced Labour (Geneva, 20I4). 
of the argument concerns not only the measures to be taken in order to put an end to such labour exploitation, ${ }^{2}$ but also the theoretical implications of its persistence in our understanding of capitalism. This debate, moreover, is not only related to contemporary reality, but also to historical dynamics, being a source of important controversies within the literature on development and labour relations. ${ }^{3}$ In fact, economists and historians have underlined the persistence of different modalities of unfree labour relationships during the past two centuries, closely related to the historical dynamics of capitalism. ${ }^{4}$ As a result, historiography focusing on the importance of forced and unfree labour for economic development has faced two main, complementary and almost always overlapping challenges: the first, mainly related to public policies and to the role of the state, is to identify the legal framework of the different modalities of unfree labour, while the second draws our attention to explaining its economic logic.

The first challenge, analysed below, is closely linked to the difficulty of giving a definition of forced labour valid for different times and places. Although coercion, both for entering into such work or to prevent workers leaving it, has long been regarded as the main factor in defining forced labour,' several historians have pointed out the necessity of broader approaches to understand the history of labour relations. ${ }^{6}$ Recently, the

2. Nicola Phillips and Fabiola Mieres, "The Governance of Forced Labour in the Global Economy”, Globalizations, I 2:2 (201 5), pp. 244-260.

3. Ibid.; Jairus Banaji, "The Fictions of Free Labour: Contract, Coercion, and So-Called Unfree Labour”, Historical Materialism, I I:3 (2003), pp. 69-95; Yann Moulier Boutang, De l'esclavage an salariat. Économie historique du salariat bridé (Paris, I998); Marcel van der Linden, Workers of the World: Essays Toward a Global Labor History (Leiden [etc.], 2008); Tom Brass, Labour Regime Change in the Twenty-First Century: Unfreedom, Capitalism and Primitive Accumulation (Chicago, IL, 20I I); Stephanie W. Barrientos, “Labour Chains': Analysing the Role of Labour Contractors in Global Production Networks", Journal of Development Studies, 49:8 (2013), pp. 1058-1071; Stephanie Barrientos, Uma Kothari, and Nicola Phillips, "Dynamics of Unfree Labour in the Contemporary Global Economy", Journal of Development Studies, 49:8 (2013), pp. I037-104I; Tom Brass, "Debating Capitalist Dynamics and Unfree Labour: A Missing Link?”, Journal of Development Studies, 50:4 (2014), pp. 570-582.

4. Tom Brass and Marcel van der Linden (eds), Free and Unfree Labour: The Debate Continues (Berne, 1997); Marcel van der Linden (ed.), Humanitarian Intervention and Changing Labor Relations: The Long-Term Consequences of the Abolition of the Slave Trade (Leiden [etc.], 201 2); Alessandro Stanziani (ed.), Labour, Coercion, and Economic Growth in Eurasia, I7th-20th Centuries (Leiden [etc.], 2013).

5. Tom Brass, "Some Observations on Unfree Labour, Capitalist Restructuring and Deproletarianization", in idem and Van der Linden, Free and Unfree Labour, pp. 57-75, 58-59; Robert J. Steinfeld, Coercion, Contract, and Free Labor in the Nineteenth Century (Cambridge, 200I).

6. Moulier Boutang, De l'esclavage an salariat; Marcel van der Linden, "Introduction", in Van der Linden, Humanitarian Intervention and Changing Labor Relations, pp. I-45; Alessandro Stanziani, "Introduction: Labour, Coercion, and Economic Growth in Eurasia, Seventeenth Early Twentieth Centuries", in Stanziani, Labour, Coercion, and Economic Growth in Eurasia, pp. I-28. 
taxonomy established by the Global Collaboratory on the History of Labour Relations at the International Institute of Social History has given us a very useful tool for furthering comparative studies on forced labour. ${ }^{7}$

This project, where the state plays an important role in shaping labour relations, as conqueror, employer, or redistributor, enables us to approach the history of labour relations by taking into account political factors. These factors include the structure of political domination over the colonies, the penitentiary system, policies towards the dissident population in the framework of a civil war, or the regulation of migratory flows. They are also essential to understanding the mechanisms shaping forced labour supply; that is, the creation of social groups susceptible to being employed in work on the margins of mercantile mechanisms. With that purpose in mind, and in order to better understand the role of the state and the global implications of imperialism for labour relations, we will analyse forced labour within Spain's legal borders during each period, including the empire.

In section three, we will deal with the second challenge, focused on two driving factors encouraging the demand for unfree labour. The first is the relative shortage of labour, something that was pointed out by Domar in his seminal article and that has been the source of several debates. ${ }^{8}$ The second relates to the possibility of increasing profits thanks to changes in the labour market that reduce the cost of labour, always keeping in mind that the margins of such profit, their relation to the levels of productivity, and their centrality in the cycles of capital accumulation remain open questions that are the subject of debate. ${ }^{9}$ Thus, what is set out here should be understood as a contribution to ongoing global debates that must necessarily be revised or enriched in the future as new studies are carried out.

7. Karin Hofmeester, Jan Lucassen, Leo Lucassen, Rombert Stapel, and Richard Zijdeman, 2016, "The Global Collaboratory on the History of Labour Relations, I 500-2000: Background, Set-Up, Taxonomy, and Applications”, http://hdl.handle.net/ro622/4OGRAD, IISH Dataverse, VI (access subject to registration), last accessed 22 August 2016. For new directions in labour history based on the taxonomy, see Leo Lucassen, "Working Together: New Directions in Global Labour History”, Journal of Global History, i I (2016), pp. 66-87. For some critical reflections on this taxonomy and the need to integrate different kinds of subaltern worker, following Van der Linden's concept of "coerced commodification of labour power", see Christian G. De Vito and Alex Lichtenstein, "Writing a Global History of Convict Labour", in Christian G. De Vito and Alex Lichtenstein (eds), Global Convict Labour (Leiden [etc.], 201 5), pp. 2-10. These authors also present us with an overall evaluation of the work of prisoners in modern history and of how it fits in with the taxonomy of the Global Collaboratory.

8. Evsey D. Domar, "The Causes of Slavery or Serfdom: A Hypothesis", The Journal of Economic History, 30: I (1970), pp. I 8-32.

9. For a theoretical analysis of the role of primitive accumulation and its relation to forced labour, see Brass, Labour Regime Change, pp. I36-166. This author also offers a critical reading of the usefulness of the concept of accumulation by dispossession, proposed by Harvey, when explaining the recourse to forced labour in the neoliberal contexts of the present. David Harvey, A Brief History of Neoliberalism (Oxford, 2005), pp. I60-165. See also Brass, "Debating Capitalist Dynamics". 


\section{POLITICAL REGIMES AND MAIN MODALITIES OF FORCED LABOUR IN SPAIN (1812-2014)}

In spite of recent research, we still lack an overall view of the persistence of forced labour in Spanish economic development. The only attempt to estimate the relative importance of the different categories of labour relations established by the Global Collaboratory on the History of Labour Relations has been made by Lana for 1797, I900, and 2001. ${ }^{10}$ However, Lana takes today's territory as a reference, and so labour relations in the colonial sphere are not included. Moreover, category i I (tributary slaves, in this case prisoners of war in concentration camps) does not figure, as the opening and closure of concentration camps in the twentieth century falls outside these temporal cross sections; nor is today's debt bondage (category I 5) included, as Lana uses official data that do not reflect these illegal situations. ${ }^{\text {I }}$

For the purposes of this article, and in order to identify different modalities of forced or unfree labour, we will take as a basis the taxonomy established by the Global Collaboratory on the History of Labour Relations and consider categories 8 (obligatory labourers), ${ }^{\mathrm{I} 2}$ I I (tributary slaves), ${ }^{13}$ Is (indentured labourers), ${ }^{14}$ and I7 (slaves who produce for the market $)^{15}$ in our analysis of forced labour, as seen in Table $\mathrm{I}$.

\section{Liberal revolution and the golden age of colonial slavery (1812-1874)}

From I 8 I 2, when the first liberal constitution was passed in Cádiz, to I 874, when a coup restored the monarchy, liberal reforms were progressively passed in Spain. Regarding labour relations, serfdom and slavery were under discussion, but while the former had disappeared during the

ı०. José-Miguel Lana-Berasain, 2016, "Spain 1800,1900,2000 [Global Collaboratory on the History of Labour Relations I 500-2000 Dataset]", http://hdl.handle.net/10622/CH6ZP5, IISH Dataverse, VI (access subject to registration), last accessed 22 August 2016.

I I. With respect to convict labour included in category 8 , I will detail my disagreements with Lana's figures for the cross sections for 1900 and $200 \mathrm{I}$ in the corresponding chronological parts. I 2. "Those who have to work for the polity, and are remunerated mainly in kind. This category includes those subject to civil obligations (corvée labourers, conscripted soldiers and sailors), and work as punishment, i.e. convicts. Hofmeester, Lucassen, Lucassen, Stapel and Zijdeman "The Global Collaboratory", p. I9.

I 3. "Those who are owned by and work for the polity indefinitely (deprived of the right to leave, to refuse to work, or to receive compensation for their labour). One example is forced labourers in concentration camps". Ibid.

I4. "Those contracted to work as unfree labourers for an employer for a specific period of time to pay off a private debt". Ibid., p. 20.

I s. "Those owned by their employers (masters). They are deprived of the right to leave, to refuse to work or to receive compensation for their labour". Ibid. 
Table I. Modalities of forced labour in Spain (I8I2-20I4) in different political and global contexts.

\begin{tabular}{|c|c|c|c|c|c|}
\hline & & $\begin{array}{c}\text { 1812-1874 } \\
\text { Liberal Revolution } \\
\text { Colonial Power / } \\
\text { Decolonization }\end{array}$ & $\begin{array}{c}1875-1936 \\
\text { Liberal Parliamentarism } \\
\text { Colonial Power / } \\
\text { Decolonization }\end{array}$ & $\begin{array}{c}\text { 1936-1975 } \\
\text { Civil War / Fascist } \\
\text { Dictatorship } \\
\text { Colonial Power / } \\
\text { Decolonization }\end{array}$ & $\begin{array}{l}\text { 1975-2014 } \\
\text { Parliamentary } \\
\text { Democracy / } \\
\text { Globalization }\end{array}$ \\
\hline \multirow[t]{2}{*}{$\begin{array}{c}\text { Tributary } \\
\text { labour }\end{array}$} & $\begin{array}{l}\text { 8. Obligatory } \\
\text { labourers } \\
\text { (State as } \\
\text { conqueror) }\end{array}$ & $\begin{array}{l}\text { - Prisoners in } \\
\text { penitentiary } \\
\text { workshops } \\
\text { - Prisoners in the } \\
\text { exterior (public } \\
\text { works and navy } \\
\text { arsenals) } \\
\text { - Prisoners in } \\
\text { North African } \\
\text { prisons } \\
\text { - Military } \\
\text { service* } \\
\text { - Prestaciones for } \\
\text { rural roads }\end{array}$ & $\begin{array}{l}\text { - Prisoners in } \\
\text { penitentiary } \\
\text { workshops } \\
\text { - Prisoners in North } \\
\text { African prisons } \\
\text { (until 1911) } \\
\text { - Provision of labour } \\
\text { (labour tax in } \\
\text { Guinea) } \\
\text { - Prisoners in Cuba } \\
\text { on sugar } \\
\text { plantations } \\
\text { (until 1898) } \\
\text { - Military service* } \\
\text { - Prestaciones for } \\
\text { rural roads }\end{array}$ & $\begin{array}{l}\text { - Prisoners in prison } \\
\text { - Prisoners outside prison } \\
\text { (until 1970) } \\
\text { - Provision of labour: } \\
\text { labour tax in Guinea } \\
\text { (gradually disappeared, } \\
\text { until 1968) } \\
\text { - Military service* }\end{array}$ & $\begin{array}{l}\text { - Prisoners in } \\
\text { penitentiary } \\
\text { workshops } \\
\text { - Military service and } \\
\text { alternative social } \\
\text { service* (until 2001) } \\
\text { - Community service } \\
\text { work* }\end{array}$ \\
\hline & $\begin{array}{l}\text { 11. Tributary } \\
\text { slaves } \\
\text { (State as } \\
\text { conqueror) }\end{array}$ & & & $\begin{array}{l}\text { - Prisoners of war (POWs) } \\
\text { in concentration camps } \\
\text { (until 1945) } \\
\text { - POWs in labour } \\
\text { battalions depending on } \\
\text { the concentration camp } \\
\text { structure (until 1945) }\end{array}$ & \\
\hline
\end{tabular}




\begin{tabular}{|c|c|c|c|c|c|}
\hline & & $\begin{array}{l}\text { 1812-1874 } \\
\text { Liberal Revolution } \\
\text { Colonial Power / } \\
\text { Decolonization }\end{array}$ & $\begin{array}{l}1875-1936 \\
\text { Liberal Parliamentarism } \\
\text { Colonial Power / } \\
\text { Decolonization }\end{array}$ & $\begin{array}{c}\text { 1936-1975 } \\
\text { Civil War / Fascist } \\
\text { Dictatorship } \\
\text { Colonial Power / } \\
\text { Decolonization }\end{array}$ & $\begin{array}{l}\text { 1975-2014 } \\
\text { Parliamentary } \\
\text { Democracy / } \\
\text { Globalization }\end{array}$ \\
\hline \multirow[t]{2}{*}{$\begin{array}{l}\text { Commodified } \\
\text { labour }\end{array}$} & $\begin{array}{l}\text { 15. Indentured } \\
\text { labourers for } \\
\text { the market } \\
\text { (State as } \\
\text { redistributor) }\end{array}$ & $\begin{array}{l}\text { - Indigenous } \\
\text { Latin } \\
\text { Americans } \\
\text { in Cuba } \\
\text { - Chinese coolies } \\
\text { in Cuba }\end{array}$ & $\begin{array}{l}\text { - Plantations in } \\
\text { Fernando Poo } \\
\text { - Coolies in Cuba } \\
\text { - Tobacco } \\
\text { plantations in } \\
\text { Philippines } \\
\text { (until 1898) }\end{array}$ & $\begin{array}{l}\text { - Plantations in Fernando } \\
\text { Poo (until 1968) }\end{array}$ & $\begin{array}{l}\text { - Trafficking and } \\
\text { indebted migrant } \\
\text { labourers } \\
\text { - Subcontracting } \\
\text { abroad by } \\
\text { companies working } \\
\text { with indebted } \\
\text { migrants** }\end{array}$ \\
\hline & $\begin{array}{l}\text { 17. Slaves } \\
\text { producing } \\
\text { for the } \\
\text { market } \\
\text { (State as } \\
\text { conqueror) }\end{array}$ & $\begin{array}{l}\text { - Slavery and } \\
\text { slave trade in } \\
\text { Cuba and } \\
\text { Puerto Rico }\end{array}$ & $\begin{array}{l}\text { - Slavery in Puerto } \\
\text { Rico and Cuba } \\
\text { (until } 1873 \text { and } \\
1886 \text { respectively) }\end{array}$ & & \\
\hline
\end{tabular}

* Neither analysed, nor calculated in this article.

** This kind of labour contract should not be included in this article if we apply the territorial criterion mentioned previously. Nevertheless, we mention it due to its importance in understanding the new accumulation cycle linked to contemporary globalization. 
eighteenth century slavery continued in these decades, during which Spain lost most of its American colonial empire.

In spite of this colonial decline, slavery became more widespread during the first half of the nineteenth century, linked to the expansion of sugar production in the framework of what Tomich has termed the "second slavery". ${ }^{16}$ For Spanish colonies, the Cuban case is the most important and well documented, owing to its role in Spanish capital accumulation. ${ }^{17}$ In spite of the agreement between England and Spain, which made the slave trade illegal after I8I7, slavery in Cuba was carried out in conditions of consensual secrecy. This agreement was no obstacle to over 500,000 Africans being landed on the island in the first half of the nineteenth century and a further 163,947 being landed in the following sixteen years, with the result that, at the end of the I 860 s, there were about 400,000 slaves on the island, ${ }^{18}$ while the island's economy depended on their work in the flourishing sugar industry. ${ }^{19}$

Within the framework of that process of economic growth, immigration through contract and the indenture of settlers from China, the so-called coolies, was also set in motion; their number reached I 20,000 between I 847 and $1874 .{ }^{20}$ These were workers who remained tied to their employers for a fixed period until they managed to meet the debt contracted for the journey, as well as the costs of their upkeep. ${ }^{21}$

16. Dale Tomich, Through the Prism of Slavery, Labor, Capital, and World Economy (Lanham, $\mathrm{MD}, 2004)$.

17. For a comparison between plantation systems in Cuba and Puerto Rico, see Antonio Santamaría García, "Las islas españolas del azúcar (1760-1898). Grandes debates en perspectiva comparada y caribeña”, América Latina en la Historia Económica, 35 (201 I), pp. I47-176.

18. Trans-Atlantic Slave Trade Database (http://www.slavevoyages.org), directed by David Eltis and Martin Halbert, last accessed 22 August 2016. For further details, see Imilcy Balboa Navarro, Los brazos necesarios. Inmigración, colonización y trabajo libre en Cuba, I878-I898 (Valencia, 2000), Imilcy Balboa Navarro, "Brazos para el azúcar. Reformas, centralización e inmigración. Cuba, I 820-I 886”, in José Antonio Piqueras (ed.), Azúcar y esclavitud en el final del trabajo forzado (Madrid, 2002), pp. 50-75; Reinaldo Funes Monzote and Dale Tomich, "Naturaleza, tecnología esclavitud en Cuba. Frontera azucarera y revolución industrial”, in José Antonio Piqueras (ed.), Trabajo libre y coactivo en sociedades de plantación (Madrid, 2009), pp. 75 -1 20; José Antonio Piqueras, "Censos lato sensu. La abolición de la esclavitud y el número de esclavos en Cuba”, Revista de Indias, 71:25 I (201 I), pp. 193-230.

19. Slavery was also a feature in other sectors of the Cuban economy, such as laying railway lines, for which Asian coolies were also deployed: Oscar Zanetti and Alejandro García, Sugar and Railroads: A Cuban History, I837-1959 (Chapel Hill, NC, 1996).

20. Balboa Navarro, Los brazos necesarios, p. 28.

2 I. Evelyn Hu-Dehart, "Chinese Coolie Labor in Cuba in the Nineteenth Century: Free Labor of Neoslavery”, Contributions in Black Studies, I 2 (1994), pp. 38-54; Consuelo Naranjo Orovio and Imilcy Balboa Navarro, "Colonos asiáticos para una economía en expansión: Cuba, I847I 880", Revista Mexicana del Caribe, 8 (I999), pp. 32-65; Benjamin N. Narvaez, "Chinese Coolies in Cuba and Peru: Race, Labor, and Immigration, I 839-1886" (Ph.D. dissertation, University of Texas, 20I0). Moreover, some 2,000 Yucatan Indians were also transported under an analogous 
With respect to convict labour, the liberal revolution meant that deprivation of liberty was established as a fundamental punishment and prison as the place for its fulfilment. There was thus a progressive elimination of sentencing to forced labour that was more typical of the ancien régime, such as sentencing to the galleys (abolished in I 803), work in the navy's arsenals (abolished in 1835 , when this was reserved for military prisoners), or work in the mercury mines of Almadén (terminated in I 800). ${ }^{22}$ So, although in the peninsula there were cases in which convicts continued to be used in public works, this practice was eliminated in the Penal Code of 1870 . As a result, throughout the century, the main experiment in captive labour took place inside the prisons, in workshops. ${ }^{23}$ The reality was quite different in the colonial territories, ${ }^{24}$ since outdoor work continued in $\mathrm{Cuba}^{25}$ and in northern Morocco, mainly in the special prisons, the so called presidios, where such work generally involved constructing and maintaining military buildings and defence infrastructures. ${ }^{26}$

system: Balboa Navarro, Los brazos necesarios, p. 29. Izaskun Álvarez Cuartero, "De Tihosuco a La Habana. La venta de indios yucatecos a Cuba durante la Guerra de Castas", Studia historica. Historia antigua, 25 (2007), pp. 559-576. On the contrary, and despite the labour problems in Puerto Rico, indentured migration was not practiced on that island. Santamaría García, "Las islas españolas", pp. I64-165.

22. Pedro A. Llorente de Pedro, "Modalidades de la ejecución penitenciaria en España hasta el siglo XIX”, Anuario de Derecho Penal y Ciencias Penales, 57 (1998), pp. 3 I I-386.

23. Prison workshops, however, were always few in number and never met the expectations of one of their main promoters, Manuel Montesinos, who was governor of several prisons and played a key role in the liberal reforms of the prison system. For labour in Spanish liberal prisons, see Pedro Trinidad Fernández, La defensa de la sociedad. Cárcel y delincuencia en España (siglos XVIII-XX) (Madrid, I99I); Justo Serna Alonso, Presos y pobres en la España del XIX (Barcelona, I988); Fernando Burillo Albacete, El nacimiento de la pena privativa de libertad (Madrid, I999). See also Pedro Oliver Olmo, "Historia y reinvención del utilitarismo punitivo", in José M. Gastón Aguas and Fernando Mendiola Gonzalo (eds), Los trabajos forzados en la dictadura franquista (Iruñea-Pamplona, 2007), pp. I 8-29; Dario Melossi and Massimo Pavarini, The Prison and the Factory: Origins of the Penitentiary System (London, 1981).

24. Recent research has shown that unfree and convict labour have played different and important roles in shaping colonial empires. See John Donoghue and Evelyn P. Jennings, "Introduction", in idem (eds), Building the Atlantic Empires: Unfree Labor and Imperial States in the Political Economy of Capitalism, ca. I500-1914 (Leiden [etc.], 2016), pp. I-24; De Vito and Lichtenstein, "Writing a Global History", pp. I0-29.

25. Yolanda Diaz Martínez, "De marginados a trabajadores. Usos y destinos de la población penal en La Habana”, Millars, XXXV (2012), pp. I29-I49.

26. Fernando Burillo Albacete, La cuestión penitenciaria. Del Sexenio a la Restauración (I8681913) (Zaragoza, 20I I). This role has similarities with that of Portuguese-African prisons, mainly oriented to infrastructure tasks during the nineteenth century, and was somehow different to British convict labour in Africa, where agricultural work played an important role: Timothy J. Coates, "The Long View of Convict Labour in the Portuguese Empire, I4I 5-I932", in De Vito and Lichtenstein, Global Convict Labour, pp. I I I-I65; Stacey Hynd, ““... a Weapon of Immense Value'? Convict Labour in British Colonial Africa, c. I 850-1950s”, in De Vito and Lichtenstein, Global Convict Labour, pp. 249-272, 257-267. 
Finally, we also should take into account the survival of some labour-tax systems for different communities during the transition to the liberal regime. One of these systems, the mita, was essential for the exploitation of silver mines in Potosí during colonial rule. ${ }^{27}$ But it should be remembered that such work was not only a colonial practice; in Spain's rural mainland, much of the work involved in repairing roads was carried out under a system of obligatory community work (the prestaciones), which was avoided by medium and large landowners who could afford to pay the corresponding daily wage. This system, created in I 845 , was continued in some localities until the first half of the twentieth century. ${ }^{28}$

\section{Industrialization, empire, and liberal parliamentarism (1875-1936)}

The period between the signing of the law that outlawed the slave trade in Cuba in I 867 and the abolition of slavery in I 886 was marked by anxiety among landowners, which led to the promotion of other modalities of forced labour, including the indebted immigration of Asians, American Indians, and even Africans under a system of contracts. Despite the attempts of public authorities, that strategy ended in failure as a global solution for labour shortages owing to the inadequate number of workers who finally arrived on the island and to the political instability prior to independence in $1898 .{ }^{29}$

Subsequently, the sugar cycle was somehow replaced in the colonies by another much more limited one, also dependent on forced forms of labour, that of cocoa, cultivated on the island of Bioko (Fernando Poo), in the Gulf of Guinea. In this case, there was considerable pressure from plantation owners to establish mechanisms to force the local population to provide labour. ${ }^{3 \circ}$ These mechanisms consisted of a labour tax, the prestaciones, ${ }^{3 \mathrm{I}}$ on the communities,

27. Rossana Barragán, "Dynamics of Continuity and Change: Shifts in Labour Relations in the Potosí Mines (I680-I 8I 2)", in the present Special Issue.

28. Francesc-Andreu Martínez Gallego, "La fuerza y la obligación: condenados, asilados y prestatarios en la obra pública española (I 834-1900)", in Santiago Castillo (ed.), El trabajo a través de la historia (Madrid, 1996), pp. 313-320.

29. Balboa Navarro, Los brazos necesarios, pp. I $23-\mathrm{I} 34$. In the Philippines, indentured migrants were also deployed on tobacco plantations towards the end of the nineteenth century: Martín Rodrigo y Alharilla, "Del desestanco del tabaco a la puesta en marcha de la Compañía General de Tabacos de Filipinas (1879-1890)", Boletín Americanista, 59 (2009), pp. 199-22 I.

30. One of them is the request of the Agriculture Chamber of Fernando Poo to the colonial governor of the island in I9IO urging him to enforce the prestaciones on the Bubi people; although a royal decree issued in 1906 had exempted the Bubi from that kind of labour tax, the governor passed a number of decrees obliging the Bubi to work. Alicia Campos Serrano, "Colonia, derecho y territorio en el Golfo de Guinea. Tensiones del colonialismo español en el siglo XX”, Quademi Fiorentini, 33/34 (2004/2005), pp. 865-898.

31. Labour tax was one of the most common ways for the authorities to ensure a labour supply from native populations and one of the basic forms of colonial state income: Marlous van Waijenburg, "Financing the African Colonial State: The Revenue Imperative and Forced Labour", African Economic History Working Paper, 20 (2015). See also Julia Seibert, "More Continuity than 
and various private contractual formulas through which workers transferred from the continent to the island were left in the hands of the landowners. ${ }^{32}$ According to Nerín, in 1917 the number of workers sent to the island was 7,233 , the majority of them transferred or held against their will. ${ }^{33}$

With respect to convict labour, it is necessary to analyse the case of colonial Cuba in the context of the abolition of slavery. Here, besides their direct use in quarries and public works benefiting the state, the leasing system, through which the state "rented" prisoners to landowners, was adopted through a decree signed in 1883 that accepted the work of prisoners on plantations, thus setting in motion their use in the sugar mills. In fact, in I 886 over half of the 393 convicts working outside the prison of La Habana did so in mills. ${ }^{34}$

On the other side of the Atlantic at the end of the century, the dismantling of the northern African prisons was the subject of a debate, in which concern was raised over what was to be done with some 3,000 prisoners who had been used for fortification and infrastructure in the north of Africa. ${ }^{35}$ The reality was that, in spite of plans to use convicts for internal colonization, ${ }^{36}$ convict labour was carried out indoors, with around a third of prisoners working in the first few years of the twentieth century and around fifty per cent in the early i 920 (accounting for 0.06 per cent of the active population in $190 \mathrm{I}) .{ }^{37}$ The last attempt to promote work as

Change? New Forms of Unfree Labor in the Belgian Congo, 1908-1930", in Van der Linden, Humanitarian Intervention and Changing Labor Relations, pp. 369-386; Kwabena O. AkurangParry, "Colonial Forced Labor Policies for Road-Building in Southern Ghana and International Anti-Forced Labor Pressures: 1900-1940”, African Economic History, 28 (2000), pp. I-25; De Vito and Lichtenstein, "Writing a Global History", pp. 30I-305.

32. Gustau Nerín i Abad, "Els inversors catalans i la conquesta del Muni (1900-1926)", Illes $i$ imperis, 8 (2006), pp. I I-1 3 I; idem, La última selva de España. Antropófagos, misioneros y guardias civiles (Madrid, 2010); Enrique Martino, "Clandestine Recruitment Networks in the Bight of Biafra: Fernando Pó's Answer to the Labour Question, I926-1945”, International Review of Social History, 57, Special Issue 20, Mediating Labour: Worldwide Labour Intermediation in the Nineteenth and Twentieth Centuries (201 2), pp. 39-72.

33. Nerín I Abad, "Els inversors catalans”, p. i I9.

34. Imilcy Balboa Navarro, "Presidiarios por esclavos. Mano de obra cautiva en la transición al trabajo libre", in Piqueras, Trabajo libre y coactivo en sociedades de plantación, pp. 253-282, 260-26I. 35. Burillo Albacete, La cuestión penitenciaria.

36. The Spanish authorities had rejected deportation and penal colonization in 1875 and later on again in the early twentieth century: Pere Gabriel, "Más allá de los exilios políticos: proscritos y deportados en el siglo XIX", in Santiago Castillo and Pedro Oliver (eds), Las figuras del desorden. Heterodoxos, proscritos y marginados (Madrid, 2006), pp. 197-22 I; Juan José Diaz Matarranz, De la trata de negros al cultivo del cacao. Evolución del modelo colonial español en Guinea Ecuatorial de 1778 a 1914 (Barcelona, 2005).

37. I must, therefore, disagree with the estimate provided for category 8 in 1900 (treating the whole prison population as workers: 24,690): Lana, "Spain I 800, 1900, 2000", p. 28. The Director General of Prisons stated in 1904 that "the majority of the approximately 17,000 inmates held by our prisons remain in sterile and injurious idleness" (cited by Burillo Albacete, La cuestión penitenciaria, p. I92), and the latest estimates by Gargallo show that in 1906 only thirty-five per cent of prisoners were 
punishment was the Vagrancy Act of 1933, but it did not result in the development of a specific system of forced labour. ${ }^{38}$

\section{Spanish Civil War and Francoist dictatorship}

After the failed coup d'etat of 1936, the ensuing civil war made possible extensive mobilization and the capture of an enormous number of prisoners of war, who had started to be used as cheap labour in non-frontline parts of Europe since World War I. ${ }^{39}$ In the zone loyal to the Republic, three modalities of forced labour were implanted at the same time as the breakdown of the penitentiary reforms guaranteeing more rights for prisoners, which had been promoted in the early $1930 .^{40}$ In December 1936 , the Ministry of Justice opened the first of a series of labour camps for rightwing prisoners, to which would be added the creation of disciplinary battalions in the army itself and the opening in 1938 of six labour camps in Catalonia run under the auspices of the Military Intelligence Service (SIM - Servicio de Inteligencia Militar), in which captives of various origins were incarcerated. ${ }^{4 \mathrm{I}}$ In total, the number of people working in captivity on the Republican side can be estimated at between 20,000 and $25,000 .^{42}$

In contrast, much more important in number and economic impact was the implementation by the Francoist side of the largest system of work in

working with a much lower percentage for women: Luis Gargallo Vaamonde, "Desarrollo y destrucción del sistema liberal de prisiones en España. De la Restauración a la Guerra Civil” (Ph.D. dissertation, Universidad de Castilla-La Mancha, 2015), pp. 627-635. In my opinion, of those included in the 1900 data the tens of thousands of conscript soldiers who were doing military service should be included in category 8. Lana puts them in category i 8.3 (commodified labour working for non-market institutions): Lana, "Labour Relations in Spain", p. 33.

38. Iván Heredia Urzaiz, "La defensa de la sociedad: uso y abuso de la Ley de Vagos y Maleantes", in Castillo and Oliver, Las figuras del desorden.

39. Gerald H. Davis, "Prisoners of War in Twentieth-Century War Economies", Journal of Contemporary History, I 2:4 (1977), pp. 623-634, 628-630. For World War II in Germany, see Mark Spoerer, Forced Labor in the Third Reich (Frankfurt am Main, 2010); Mark Spoerer and Jochen Fleischhacker, "Forced Laborers in Nazi Germany: Categories, Numbers, and Survivors", Journal of Interdisciplinary History, XXIII:2 (2002), pp. 169-204; Marc Buggeln, Slave Labor in Nazi Concentration Camps (Oxford, 20I4). For the USSR, see Paul Gregory and Valery Lazarev (eds), The Economics of Forced Labor: The Soviet Gulag (Stanford, CA, 2003). For a comparison of the use of forced labour between Japan and Germany in the two world wars, see Mark Spoerer, "Zwangsarbeitsregimes im Vergleich. Deutschland und Japan im Ersten und Zweiten Weltkrieg", in Hans-Christoph Seidel and Klaus Tenfelde (eds), Zwangsarbeit im Europa des 20. Jahrhunderts. Bewältigung und vergleichende Aspekte (Essen, 2007), pp. I 87-226.

40. Luis Gargallo Vaamonde, El sistema penitenciario de la Segunda República. Antes y después de Victoria Kent (193I-1936) (Madrid, 20I I).

4I. Francesc Badia, Els camps de treball a Catalunya durant la Guerra Civil (1936-1939) (Barcelona, 200I).

42. Julius Ruiz, “'Work and Don't Lose Hope': Republican Forced Labour Camps during the Spanish Civil War", Contemporary European History, i 8:4 (2009), pp. 419-44I. 
captivity seen in twentieth-century Spain, starting in spring 1937 with the creation of the Concentration Camp Inspectorate for Prisoners of War (ICCP - Inspección de Campos de Concentración de Prisioneros) and the publication of the Decree on the Concession of the Right to Work to Prisoners and Prisoners of War, which heralded the two great modalities of forced labour during the dictatorship. ${ }^{43}$

The first of these, numerically more significant although more short-lived, was structured on the basis of battalions depending on the ICCP and comprising POWs classified as being opposed to the regime or of doubtful loyalty. These were named Workers' Battalions (BBTT - Batallones de Trabajadores) between 1938 and I940, and Disciplinary Battalions of Worker-Soldiers (BDST - Batallones Disciplinarios de Soldados Trabajadores) from 1940 until they were disbanded, the majority in 1942 and the rest in 1945. At their highpoint, at the end of the war, the BBTT included some 90,000 POWs, although the number fell to about 40,000 between 1939 and $1942 .{ }^{44}$

The second modality began to be constituted in 1938 , with the System of Punishment Redemption through Work for prisoners who had previously been tried. This system encompassed not only the new prison workshops, but also modalities of extramural work, such as the Militarized Penitentiary Colonies ${ }^{45}$ or the Penal Detachments. ${ }^{46}$ The number of convict workers

43. The text of the decree is very explicit about the obligation to work: "Such a right to work is preceded by the idea of right-function, or right-duty, and, if necessary, right-obligation". Boletin Oficial del Estado, I June I937.

44. Fernando Mendiola Gonzalo, "Forced Labor, Public Policies, and Business Strategies During Franco's Dictatorship: An Interim Report”, Enterprise E Society, I 4:I (2013), pp. I 82-2 I3. For further information, see Javier Rodrigo, Cautivos, campos de concentración en la España franquista, 1936-1947 (Barcelona, 2005); Fernando Mendiola Gonzalo, "Reeducation Through Work? Mountain Roads in the Spanish Concentration Universe (Western Pyrenees, 1939-1942)", Labor History, 55:I (2014), pp. 97-1 I6. The classification of concentration camp POWs as slaves has also been a subject of historiographical debate: Cord Pagenstecher, "We Were Treated Like Slaves': Remembering Forced Labor for Nazi Germany”, in R. Hörmann and G. Mackenthun (eds), Human Bondage in the Cultural Contact Zone: Transdisciplinary Perspectives on Slavery and Its Discourses (Münster, 2010), pp. 275-291; Marc Buggeln, "Were Concentration Camp Prisoners Slaves? The Possibilities and Limits of Comparative History and Global Historical Perspectives", International Review of Social History, 53:I (2008), pp. I0I-I 29; Alexander von Plato, “'It was Modern Slavery': First Results of the Documentation Project on Forced and Slave Labour", in Alexander von Plato, Almut Leh, and Christoph Thonfeld (eds), Hitler's Slaves: Life Stories of Forced Labourers in Nazi-Occupied Europe (New York and Oxford, 2010), pp. 44I484; Spoerer and Fleischhacker, "Forced Laborers in Nazi Germany", pp. 172-176.

45. These colonies where under public control: Gonzalo Acosta Bono et al., El Canal de los Presos (1940-1962). Trabajos forzados. De la represión política a la explotación económica (Barcelona, 2004), pp. 8 I-IOI.

46. These detachments were placed with private companies, to which the state "leased" the prisoners: Alicia Quintero, "Sistema penitenciario durante el primer franquismo. Los destacamentos penales", paper presented at II Encuentro de Jóvenes Investigadores en Historia Contemporánea de la AHC, Granada, 2009. 
peaked at 24,844 in 1943 , from when it started to fall in line with the decline in the size of the prison population, remaining below I0,000 in the I950s. Following a boom in exterior work in the early years after the civil war, under Francoism forced labour was progressively withdrawn to the interior of the prisons. As noted, the system regulating this work was basically Punishment Redemption, but the 1946 Regulation on Penitentiary Work nonetheless left the door open to work of a compulsory character, with the result that the Francoist prisons housed a growing percentage of working captives. ${ }^{47}$

If we analyse these figures in terms of the long-term evolution of captive labour in Spain, we must emphasize that it was in the immediate aftermath of the civil war, in I940, that convict labour was at its most important, with I08,78 I prisoners and POWs working, I.I 6 per cent of the total active population..$^{48}$

Finally, and in relation to imperial policies prior to decolonization, we must note that, although declining in importance, the labour-tax system of prestaciones was maintained by the dictatorship, while the main efforts of colonial rulers focused on encouraging indentured and contract migration networks. ${ }^{49}$

\section{Unfree labour in parliamentary democracy within a globalizing context}

For post-Francoist Spain, we must take account of contemporary forms of unfree labour in the framework of globalization and the formation of global supply and value networks. ${ }^{50}$ These forms, which some authors have conceptualized as "new slavery", ${ }^{\mathrm{I}}$ involve millions of workers all over the

47. Acosta Bono et al., El Canal de los Presos; Domingo Rodrıguez Teijeiro, Las carceles de Franco (Madrid, 20II); Mendiola Gonzalo, "Forced Labor", pp. 21 I-2I2; José R. González Cortés, "Bibliografía de lo punitivo. Los estudios sobre los trabajos forzados del franquismo", in Pedro Oliver Olmo and Jesús C. Urda Lozano (eds), La prisión y las instituciones punitivas en la investigación histórica (Cuenca, 2014), pp. 597-614. Under the Vagrancy Act of 1933, during the dictatorship captives, many of them homosexuals, were also forced to work in the Penitentiary Colony of Tefía, in the Canary Islands.

48. For further details, see Mendiola Gonzalo, "Forced Labor". This average percentage does not indicate the importance of forced labour in some specific sectors. In Basque iron-mining, an economically strategic sector, the proportion reached 19.4 per cent in 1938: Fernando Mendiola Gonzalo, "El impacto de los trabajos forzados en la economía Vasconavarra (I937-1945)", Investigaciones de Historia Económica, 8:5 (2012), pp. 104-1 16, I07.

49. Alicia Campos Serrano, "El régimen colonial franquista en el Golfo de Guinea", Revista Jurídica Universidad Autónoma de Madrid, 3 (2000), pp. 79-108, 98-102; Martino, "Clandestine Recruitment Networks".

50. For value and supply chains, see Jean Allain et al., Forced Labour's Business Models and Supply Chains (York, 2013), pp. 39-53; Nicola Phillips, "Unfree Labour and Adverse Incorporation in the Global Economy: Comparative Perspectives on Brazil and India", Economy and Society, 42:2 (2013) pp. I7I-196.

5. Kevin Bales, Disposable People: New Slavery in the Global Economy (Berkeley, CA, 1999); idem, Understanding Global Slavery (Berkeley, CA, and London, 2005). Recent estimates for Europe can be found in idem, "Slavery in Europe: Part I, Estimating the Dark Figure", Human Rights Quarterly, 35:4 (2013), pp. 817-829. 
world, many of them in situations of indentured labour, often as a result of clandestine migratory movements. ${ }^{52}$

Within the previously explained category 8 of the Collaboratory's taxonomy, the end of compulsory military service in $200 \mathrm{I}$ meant that work in prisons was the only type of labour relationship. In fact, it was not completely compulsory, but different testimonies and research have pointed out that refusing work in prison adversely affected a prisoner's chances of being granted parole. ${ }^{53}$ Thus, what should be included in the totals provided by Lana ${ }^{54}$ for category 8 in $200 \mathrm{I}$ is the total number of prisoners working in the prisons, which that year totalled 9,566, accounting for 0.05 per cent of the active population. ${ }^{55}$ The majority of the 16,246 prisoners working in Spanish prisons in 2013 were doing so in the maintenance services of the prison itself, although over 3,000 did so in workshops of private companies established within the prisons. ${ }^{56}$ One of the great methodological difficulties and challenges facing researchers is having precise data on company participation in penitentiary workshops, since the official memoranda do not provide them, and we have only partial information through the denunciations of prisoners and solidarity collectives, for both the $1970 s^{57}$ and the present. ${ }^{58}$

52. For overall figures: ILO, Profits and Poverty. For structural coercion as one of the keys to understanding migrants' debt bondage, see Genevieve LeBaron, "Reconceptualizing Debt Bondage: Debt as a Class-Based Form of Labor Discipline”, Critical Sociology, 40:5 (2014), pp. 763-780.

53. See, for example, this prisoner's answer to a research questionnaire: "If you refuse to work, reprisals are immediate: they won't give you permissions": Observatori del Sistema Penal i els Drets Humans, L'empresonament a Catalunya (Barcelona, 2004), p. 26I. This other prisoner, J. Solis, recently declared that "You had to sign that labour contract to have some rights; therefore, it was a complete coercion": Víscera, "Contra los muros. Diálogo visceral con Amadeu Casellas y José Solís”, Viscera, 4 (2010), p. 8. 54. Lana, "Spain I 800, 1900, 2000", p. 43.

55. Data on prisoners' work are available separately for Catalonia and the rest of Spain. For Catalonia: Departament de Justícia, Memòria del Departament de Justícia 200 I (Barcelona, 200I), p. 278, available at http://justicia.gencat.cat/web/.content/documents/arxius/doc_43044028_I.pdf, last accessed 22 August 2016; for the rest of Spain: Ministerio del Interior, Informe General 200I, Dirección General de Instituciones Penitenciarias (Madrid, 200I), p. 218, available at http://www.institucionpenitenciaria.es/ web/export/sites/default/datos/descargables/publicaciones/IFNORME_200I.pdf, last accessed 22 August 2016.

56. For Catalonia: Departament de Justícia, Memòria del Departament de Justícia 2013 (Barcelona, 20I3), p. I80, available at http://justicia.gencat.cat/web/.content/documents/publicacions/memoria_2013/memoria_justicia_2013.pdf, last accessed 22 August 2016; for the rest of Spain: OATPFE, Memoria 2013 del Organismo Autónomo Trabajo Penitenciario y Formación para el Empleo (Madrid, 20I3), p.IO, available at http://www.oatpfe.es/docs/20I4/07/24/I233000I_4_2_o.pdf, last accessed 22 August 2016. For the evolution of Spanish prisons after Franco's dictatorship, see César Lorenzo Rubio, "Modernización y segregación en las prisiones de la democracia", in Pedro Oliver Olmo (ed.), El siglo de los castigos. Prisión y formas carcelarias en la España del siglo XX (Barcelona, 20I3), pp. IOI-I43. The rise between $200 \mathrm{I}$ and 2013 is due mainly to the efforts of prisons to involve more and more prisoners in daily work.

57. Colectiu Arrán, "La lucha en la cárcel en la España de los años 70. Trabajos penitenciarios / Talleres penitenciarios de Carabanchel”, Panóptico, 5 (2003), pp. I78-I86, I82-I 84.

58. Amadeu Casellas Ramón, Un reflejo de la sociedad. Crónica de una experiencia en las cárceles de la democracia (Barcelona, 2014), pp. 337-339. 
Outside the prisons, in the Spanish case situations of "new slavery" are basically linked to processes of indebtedness of migrants, the number of which Bales estimates at around 6, I 16 in 2009. ${ }^{59}$ With respect to sectors of work, there are no monographic studies, but there is information on forced labour practices in agriculture, ${ }^{60}$ in the building industry, ${ }^{61}$ in domestic service, ${ }^{62}$ and in prostitution. ${ }^{63}$

Finally, although the deployment of forced labourers is today generally considered only within the context of Spain's borders, we must also consider the use of forced labour by Spanish companies operating internationally - and which is therefore beyond the scope of Spanish legislation. There are, once again, methodological difficulties in clarifying this question owing to the opacity of subcontracting systems and the lack of validity of commitments made, as in the case of Inditex, ${ }^{64}$ a company publicly accused of using immigrant workers under debt bondage in workshops in Argentina ${ }^{65}$ and Brazil. ${ }^{66}$ Moreover, cases have also been confirmed in

59. Bales, "Slavery in Europe", p. 827. Due to the clandestine character of this situation, it is impossible to quantify this exactly. Bales has continued to refine this quantification, resulting in this new estimate for 2009, lower than the previous one, of between 10,000 and I 5,000 , for the early years of the twenty-first century, prior to the economic crisis that started in 2008 . In any case, the still unknown number of workers included in category is should be added to the figures provided by Lana ("Spain I $800,1900,2000$ ", p. 43) on labour relations in $200 \mathrm{I}$, based on the $200 \mathrm{I}$ Census in which, obviously, these workers are not recorded.

6o. Rodrigo García Schwarz, Rompiendo las cadenas de una ciudadanía cautiva (Madrid, 20I I), pp. 24I-242; one recent article in The Guardian reported that Spanish police had information about this situation, their only concern being to avoid migrants reaching tourist locations: Felicity Lawrence, "Spain's Salad Growers are Modern-Day Slaves, Say Charities", The Guardian, 7 February 20II, available at http://www.theguardian.com/business/20II/feb/o7/spain-saladgrowers-slaves-charities, last accessed 22 August 2016.

6. García Schwarz, Rompiendo las cadenas.

62. Office of the Special Representative and Coordinator for Combating Trafficking in Human Beings, "Unprotected Work, Invisible Exploitation: Trafficking for the Purpose of Domestic Servitude", OSCE Occasional Paper Series, 4 (2010), p. го.

63. Luis Gargallo Vaamonde and María Sánchez Fernández, "El tráfico de mujeres para su explotación sexual. Una esclavitud invisible”, Revista General de Derecho Penal, I6 (201 I); ILO, Profits and Poverty, p. I7.

64. For the agreement between Inditex and the International Textile, Garment and Leather Workers' Federation (ITGLWF), see ILO, The Cost of Coercion, p. 58.

65. Ana Delicado, "Zara recurre al trabajo esclavo en Argentina”, Público, 8 April 20 I3, available

at http://www.publico.es/internacional/453287/zara-recurre-al-trabajo-esclavo-en-argentina, last accessed 22 August 2016.

66. Agencia EFE, "Brasil expedienta a Zara por un escándalo de esclavitud en Sao Paulo", La Vanguardia, I8 August 20II, available at http://www.lavanguardia.com/internacional/ 20I I 08 I 8/5420 I 597972/brasil-expedienta-a-zara-por-un-escandalo-de-esclavitud-en-sao-paulo. html, last accessed 22 August 20I6; José Manuel Rambla, "Brasil amenaza con sancionar a Zara por utilizar mano de obra esclava", Nueva Tribuna, is May 20 I 5 , available at http://www.nuevatribuna.es/ articulo/america-latina/brasil-amenaza-sancionar-zara-75-millones-euros-utilizar-mano-obra-esclava/ 20 I 505 I 3 I 84608 I I 5934.html, last accessed is November 2016. 
fishing companies, ${ }^{67}$ and in the building sector by one of the subcontractors for the Spanish company OHL, which is involved in construction work on the stadiums being used for the Football World Cup in Qatar. ${ }^{68}$ Clearly, these are all isolated cases, but they reveal the existence of a submerged global economy that Spanish multinational companies are also taking advantage of, in the framework of the new global value and supply chains. ${ }^{69}$

\section{THE DRIVING FORCES BEHIND DEMAND: RELATIVE SCARCITY AND ACCUMULATION CYCLES}

\section{The relative scarcity of labour power}

Labour scarcity is considered a key factor for understanding the recourse to forced labour. ${ }^{70}$ Nonetheless, this has also been questioned by many authors, not only because in some specific situations labour shortage does not serve as an explanatory factor, ${ }^{7 \mathrm{I}}$ but also because on occasions it is precisely an element that facilitates a dissolution of coercive bonds specific to labour because of the effects of the option to abandon the work, the so-called outside option effect. ${ }^{72}$ In any case, all these approaches stress that scarcity must be understood in a relative way, something that is confirmed, too, in the Spanish case.

In the case of the so-called second slavery in colonial Cuba, it is beyond dispute that this recourse to slavery was the way to implement a process of expansion that required - in keeping with the process of sugar-mill mechanization and the logic of economies of scale - an extensive use of labour that was not available on the island at that time. ${ }^{73}$ We must consider,

67. “¿Somos marinos o esclavos?”, Boletín de los Marinos, Federación Internacional de los Trabajadores del Transporte, 22 (2008).

68. Amnesty International, The Dark Side of Migration: Spotlight on Qatar's Construction Sector Ahead of the World Cup (London, 2013), pp. 79-82.

69. Since labour relationships lie within the legal framework of the country where they take place, and, moreover, most of the supplier enterprises are independent of the main one, the Spanish government and the courts have kept themselves apart from this reality.

70. Domar, "The Causes of Slavery". More recently, and in a broader sense, transaction-costs economists have remarked that "hierarchy is favored as asset specificity builds up": Oliver E. Williamson, "The Theory of the Firm as Governance Structure: From Choice to Contract", Journal of Economic Perspectives, I6:3 (2002), pp. I7 I-195, I 8 I.

71. Linden, Workers of the World, pp. 39-54; Moulier Boutang, De l'esclavage an salariat, pp. 66I-672; Erik Green, "The Economics of Slavery in the Eighteenth-Century Cape Colony: Revising the Nieboer-Domar Hypothesis", International Review of Social History, 59:I (2014), pp. 39-70.

72. This is the case, for example, with the crisis in the Low Middle Ages, when labour shortage related to demographic collapse resulted in very different labour regimes depending on the political situation: Daron Acemoglu and Alexander Wolitzky, "The Economics of Labor Coercion”, Econometrica, 79:2 (201 I), pp. 555-600, 587-588.

73. Balboa Navarro, Los brazos necesarios; Funes and Tomich, "Naturaleza, tecnología esclavitud en Cuba". 
as we shall see later when analysing accumulation strategies, that other types of alternative were ruled out, due precisely to their greater cost. A similar situation took place on the cocoa plantations of Fernando Pó at the end of the nineteenth century, although on a much smaller scale. Here, too, recourse to the imposition of forced labour was linked to complaints on the part of plantation owners about the need for labourers for the cocoa harvest; those plantation owners formed a pressure group, which pushed the Spanish government to retain the continental territory of Muni as a labour reserve for the island. ${ }^{7}$

Secondly, attention must be paid to the only period of modern Spanish history when it is possible to speak of a shortage of labour in a strict sense: the period of the Spanish Civil War, in the framework of global mobilization, repression, and exile, when the Spanish economy suffered a great loss of human capital. ${ }^{75}$ There was a very different intensity in the use of forced labour on the two sides during the war, which once again leads us to diminish the significance of this factor. Recent research has shown that in specific situations a scarcity of labour acted as a key element in the demand for forced workers while, in an opposite sense, the end of such scarcity led some companies to actually request that forced workers be replaced by other, free workers. Examples include some mining companies in Biscay and the MZA railway company. The latter initially justified its request for prisoners as being due to the "scarcity of our own workers", while months later, once the war had ended, it requested the replacement of a Workers' Battalion by free workers, arguing that the latter were more productive. ${ }^{76}$ This overall shortage of labour ended with the war, not so much because losses in terms of demography or human capital were recovered, but because of the lack of economic dynamism and the slow pace of economic recovery. ${ }^{77}$

Thirdly, account must be taken of the spectacular demand for labour in the last expansive cycle of the Spanish economy, between 1996 and 2007. This was a period when new jobs were created at a much higher pace in

74. Nerín I Abad, La última selva.

75. Clara E. Núñez Romero Balmas, "El capital humano en el primer franquismo", in Carlos Barciela López (ed.), Autarquía y mercado negro. El fracaso económico del primer franquismo, 1939-1959 (Barcelona, 2003), pp. 27-54.

76. Fernando Mendiola, "Of Firms and Captives: Railway Infrastructures and the Economics of Forced Labour (Spain, 1937-1957)”, Revista de Historia Industrial (forthcoming, 2017). On Basque mining see Fátima Pastor Ruiz, El Batallón Minero $n^{\circ}$ I en las minas de Vizcaya (Bilbao, 2010); Mendiola Gonzalo, "El impacto".

77. Jordi Catalán, "La reconstrucción franquista y la experiencia de Europa occidental, 19341949”, in Barciela López (ed.), Autarquía y mercado negro, pp. I23-168; for labour deployment during these years, see Leandro Prados de la Escosura and Joan R. Rosés, "Human Capital and Economic Growth in Spain, 1850-2000", Explorations in Economic History, 47:4 (2010), pp. $520-532,528$. 
Spain than in Europe as a whole, due to the labour-intensive and natural resource-intensive character of the country's economic growth, which was linked to property expansion and construction work. ${ }^{78}$ In this context, the growing demand for labour, concentrated in more precarious and less well-paid jobs, was largely satisfied thanks to one of the spaces most favourable to forced labour: illegal immigration. ${ }^{79}$

These cases show us that, in reality, scarcity must be analysed in relative rather than absolute terms, in terms of the elasticity of demand for labour being higher than the elasticity of supply, while other options that could clearly be costlier to employers must also be analysed. This applies not only to the three situations set out, but also to others in which relative scarcity must be understood according to seasonal, sectoral, territorial, or legal criteria.

The scarce population of certain regions has also been used as a factor explaining the recourse to forced labour, due to the extra costs that could be involved for companies or the state in transferring population to those zones. Internal colonization in areas with a low population density was one option considered at the start of the twentieth century for relocating convicts in African prisons, ${ }^{80}$ and it appears subsequently as one reason for deploying forced labour during the Spanish Civil War. ${ }^{8 \mathrm{I}}$ Moreover, the opening up of transport infrastructures in sparsely populated regions was a significant problem during the Francoist dictatorship, so recourse was made to Workers' Battalions to open up roads in parts of the Pyrenees, and also to prisoners to open up railway lines. ${ }^{82}$

78. Isidro López and Emmanuel Rodríguez, “The Spanish Model”, New Left Review, 69 (201 I), pp. 5-28. The centrality of migration for the expansion of labour force is clear: from 1994 to 2008 Spain's active population increased 40.9 per cent, and this growth was due more to migrants $(3,347,400)$ than to Spanish workers $(3,207,500)$. The former accounted for 0.6 I per cent of the active population in 1994 and I 5.26 per cent in 2008. Miguel Pajares, Inmigración y mercado de trabajo. Informe 2009 (Madrid, 2009), pp. 26-27. It should also be noted that unemployment fell sharply between 1994 ( 22 per cent) and 2007 (8.2 per cent), the year before the crisis, a rate quite similar to that for the eurozone as a whole (7.5 per cent): available at http://ec.europa.eu/eurostat, last accessed 22 August 2016.

79. In 2009, there were $1,449,968$ immigrants with a temporary residence permit and about 900,000 in a situation of illegality: Eduardo Romero, Un deseo apasionado de trabajo más barato y servicial (Oviedo, 2010), pp. I34-135. See also Pajares, Inmigración y mercado de trabajo.

8०. The only practical result of this was the opening of the "El Dueso" penitentiary colony in Santoña: Burillo Albacete, La cuestión penitenciaria.

8I. The labour camps created by the Republican Ministry of Justice in 1936 were essentially agricultural, while in the Francoist zone internal colonization was already the goal of forced labour policies, as can be seen in ICCP memoranda, and also in the case of La Cabrera in León: Juan Carlos García-Funes, "A recoger bombas". Batallones de trabajo forzado en Castilla y León (Seville, 2016).

82. On mountain roads: Fernando Mendiola and Edurne Beaumont, Esclavos del franquismo en el Pirineo (Tafalla, 2006), and Mendiola Gonzalo, "Reeducation Through Work?". On railway infrastructures: Mendiola, "Of Firms and Captives". 
Relative scarcity combined with seasonality is another factor that must be taken into account when explaining the recourse to coercion. Agriculture has always been a sector strongly marked by seasonality in the distribution of labour, and that continues to be the case today. This means that it is a sector conducive to the use of labour supply chains for ensuring the presence of workers at the required time owing to its particular characteristics and the existence of highly labour-intensive tasks for short periods of time.$^{83}$ It is precisely in special situations, like the harvest, that cases of exploitation of immigrants have been found to border on forced labour. ${ }^{84}$ The influence of the greater demand for labour in summer has historically meant that during this season other sectors can be negatively affected by a scarcity of labour or a rise in wages. In fact, in the account of the virtues of work in the Memorandum of the General Directorate of Prisons (DGP) it is explained that recourse to convict labour also served to stabilize the number of workers in the construction sector "at critical seasonal times". ${ }^{85}$

Finally, regarding labour shortage we must consider the relationships between qualification levels and the intensity of work. Indeed, the case of one Basque province, Bizkaia, shows, as in most of the cases that appear in Table I, that forced labourers were deployed mainly in low-qualification and effort-intensive tasks, ${ }^{86}$ such as mining and construction, where the presence of captive workers in industry was much lower. Nevertheless, when necessary those industries requested prisoners or POWs with very specific skills. ${ }^{87}$

Another peculiarity, in this case related to the low elasticity of supply for labour, is that of illegal activities, where forced labour provides an easy

83. Allain et al., Forced Labour's Business Models, pp. 42-43 and 47-49.

84. García Schwarz, Rompiendo las cadenas. Barrientos has confirmed the presence today of supply chains bringing workers from Africa to English agriculture, through which farmers have access to labourers subjected to debt bondage: Barrientos, "Labor Chains", p. 1063. The importance of seasonality, of course, must also be understood in its political and legal framework.

85. Dirección General de Prisiones, Memoria de la Dirección General de Prisiones (Madrid, 1956), p. 73. A similar logic has been found in the post-slavery southern USA and in colonial India: Alex Lichtenstein, Trwice the Work of Free Labor: The Political Economy of Convict Labor in the New South (London and New York, NY, 1996), pp. 46-47; Chitra Joshi, "Public Works and the Question of Unfree Labour", in Stanziani, Labour, Coercion, and Economic Growth in Eurasia, pp. $273-287,285-287$.

86. This positive correlation between effort and coercion was underlined long ago by Fenoaltea: Stefano Fenoaltea, "Slavery and Supervision in Comparative Perspective: A Model", Journal of Economic History, 44:3 (I984), pp. 635-668. It has been widely accepted in the literature: Acemoglu and Wolitzki, "The Economics of Labor Coercion". Historical research has proved that coercion and forced labour have also been present in skilled tasks, mainly through incentives: Van der Linden, Workers of the World, p. 50.

87. Mendiola Gonzalo, "Forced Labor"; idem, "El impacto". 
solution to variations in demand. ${ }^{88}$ Therefore, we must again emphasize that scarcity, though central to understanding the demand for forced labour, must be analysed also taking into account a number of other economic and political factors.

\section{Forced labour and cycles of capital accumulation}

As we have seen in the previous section, the option of forced labour must not be seen as something necessary, but as arising from the balance of forces between labour and capital in different legal frameworks that make it easier for the latter to impose a modality of forced labour, yielding it greater profits or ensuring labourers that would otherwise have been more difficult, or more expensive, to find. ${ }^{89}$ Put another way, it is necessary to consider these coercive mechanisms of labour recruitment not only as something characteristic of primitive accumulation prior to capitalism, but also as one of the options used intermittently over the course of its historical development in new cycles of accumulation, as proposed by Brass in the concept of "deproletarianization"..$^{\circ}$

With respect to the Spanish case, I believe that there were three great cycles of capital accumulation during the past two centuries that were based to a certain (and different) extent on the utilization of forced labour: colonial slavery, forced labour under Francoism, and the appearance of new forms of forced labour within the framework of the upward cycle of 1996-2008.

In the case of slavery, the Cuban experience provides a good example of how relations of slavery can be immersed within the cycle of production and accumulation linked to a new world division of labour, not only in the stages prior to capitalist industrialization, as proposed by Williams, but also during the process of industrialization. ${ }^{9 \mathrm{I}}$ Moreover, profits generated by slave labour were not only reinvested in the sugar economy, but also used to further the industrializing process in the metropolis, especially in Catalonia.

88. Andrew Crane, "Modern Slavery as a Management Practice: Exploring the Conditions and Capabilities for Human Exploitation", Academy of Management Review, 38:I (2013), pp. 49-69, 54. 89. Of course, coercion costs (police, frontier controls, prisons, concentration camps) linked to unfree labour are often paid by the state, and not by the employers.

90. Brass, "Some Observations on Unfree Labour", pp. 7I-74; idem, "Debating Capitalist Dynamics".

91. Williams holds that commercial capitalism promoted and benefited from slavery, while industrial capitalism destroyed it: Eric Williams, Capitalism and Slavery (Chapel Hill, NC, 1944).

Taking a different approach, Tomich, Through the Prism of Slavery, pp. 17-27 and 56-71, has pointed out that it is necessary to insert this "second slavery" into the capitalist expansion of the early nineteenth century. See also Michael Zeuske, "Historiography and Research Problems of Slavery and the Slave Trade in a Global-Historical Perspective", International Review of Social History, 57:I (20I2), pp. 87-III. 
This was the case both during the central decades of the nineteenth century and after I 898, when Spain underwent a great investment cycle principally motivated by the arrival of capital from Cuba and other areas of Latin America. ${ }^{92}$ The central role of forced labour with respect to capital accumulation was such that the Cuban elites made an effort to extract the greatest possible output from the system, even when slavery was about to be abolished. ${ }^{93}$

The second cycle in which we can relate capital accumulation and forced labour is the Spanish Civil War and the initial period of Francoism. While capital accumulation and the fall in wages must be framed in terms of the transformation of the labour market and the political repression of the time, ${ }^{94}$ forced labour, in spite of the productivity problems it entailed, also contributed to that capital accumulation, ${ }^{95}$ while functioning at the same time as a key tool to discipline the working population. ${ }^{96}$ With respect to

92. Ángel Bahamonde Magro and José Cayuela Fernández, "Traficantes, armadores y hacendados. Elite colonial hispano-cubana y trasvase de capitales a finales del siglo XIX", Studia Historica, Is (1997), pp. 9-20; Luis Alonso Álvarez, "Comercio exterior y formación de capital financiero: el tráfico de negros hispano-cubano, i 82 I-I 868”, Anuario de Estudios Americanos, 5 r:2 (1994), pp. 75-92; Michael Zeuske and Orlando García Martínez, "La Amistad de Cuba: Ramón Ferrer, contrabando de esclavos, captividad y modernidad atlántica”, Caribbean Studies, 37 (2009), pp. 97-170; Martín Rodrigo y Alharilla, "Los Goytisolo. De hacendados en Cienfuegos a inversores en Barcelona”, Revista de Historia Industrial, 23 (2003), pp. I I-37; Martín Rodrigo y Alharilla, "Los amargos beneficios del dulce. Azúcar, Cuba y deuda ecológica", Anuario de Estudios Americanos, 63:I (2006), pp. 2 I I-232.

93. José Antonio Piqueras, "El capital emancipado. Esclavitud, industria azucarera y abolición en Cuba”, in Piqueras, Azúcar y esclavitud, pp. 2 I 4-25 I. To replace increasingly expensive and scarce slaves, landowners opted for Asian indentured immigrants, rejecting government attempts to encourage the immigration of free Spanish workers who would be more politically loyal, but more expensive as labour: Balboa Navarro, Los brazos necesarios, pp. $165-176$. Highly illustrative is the complaint of the Plenipotentiary Minister of Spain in Peking in 1878 , who stated that "The Cuban landowners did not want to understand that they had to make a brusque but essential conversion from the work of slaves to that of labourers, and on becoming convinced that they could no longer extract blacks from Africa, they have gone to Asia for yellow men, reducing the whole transition to one of colour" (Balboa Navarro, Los brazos necesarios, p. I 24).

94. Margarita Vilar Rodríguez, Los salarios del miedo. Mercado de trabajo y crecimiento económico en España durante el franquismo (Santiago de Compostela, 2009). See also Margarita Vilar, "'The Labour Market under the Iron Fist of the State': The Franco Dictatorship in the Mirror of Hitler, Mussolini and Stalin", European Review of History: Revue europeenne d'histoire, 20:3 (2013), pp. 427-443.

95. Lower productivity among POWs with respect to prisoners has been demonstrated for Franco's Spain: Mendiola Gonzalo, "Forced Labor", pp. 198-203. In Nazi Germany, the lower productivity of forced labourers has been proved to be compatible with higher profits for enterprises, due to the extremely low costs of labour: Mark Spoerer, "Profitierten Unternehmen von KZ-Arbeit? Eine kritische Analyse der Literatur”, Historische Zeitschrift, 268: I (1999), pp. 6 I-95. 96. Rodrigo, Cantivos; Acosta Bono et al., El Canal de los Presos; Gutmaro Gómez Bravo, La redención de penas. La formación del sistema penitenciario franquista (Madrid, 2008); Mendiola Gonzalo, "Reeducation through Work?" This political function of forced labour, with clear repercussions on the transformation of the labour market and the evolution of wages, has been 
the private sector, forced labour made possible direct profits for the companies that used it, and this has also been conceptualized by Sánchez Albornoz as being similar in a certain sense to primitive accumulation. ${ }^{97}$ While, in principle, companies had to pay the state the same wage as that stipulated for free workers in each locality, there were different mechanisms for drawing additional profit from convict workers: paying a lower salary than that paid to free workers in remote areas; the possibility of redirecting foodstuffs intended for the prisoners to the black market; lengthening the working day; or even, in some cases, refusing to pay the state for the use of captive workers. ${ }^{9}$ In addition, it is necessary to include as private profit the irrigation of substantial areas of land belonging to large landowners by means of forced labour, as was the case with the Guadalquivir Canal. ${ }^{99}$ For its part, the public sector also obtained significant profits as the main employer of forced workers. On the one hand, due to work on public infrastructure such as roads and railways, which involved the work of thousands of POWs and, on the other, due to the money the state Treasury received from the companies that used prisoners. In the case of the Biscayan mining companies, Pastor ${ }^{100}$ has calculated that the state made a profit of 55.3 per cent on company payments, while the memoranda of the DGP in I939 raised this figure to 76 per cent. ${ }^{\text {IOI }}$

The third cycle of Spanish accumulation in which unfree labour has played a significant role is linked to the property and construction expansion of recent decades. While new studies are still needed that could confirm what was indicated by Romero, ${ }^{102}$ immigration involving debt and the situation of illegality have enabled a substantial accumulation of profits thanks to the existence of a pocket of workers in a precarious, irregular, or illegal situation. They have been willing to work in conditions worse than those stipulated by law, and also, in some cases, in a situation of provisional servitude until the contracted debt is paid off. With respect to work in prison, it is once again necessary to refer to a double type of profit. On the one hand, public, as the tendency to replace free work by captive work in

underscored by Roth for the case of Nazi Germany: Karl H. Roth, "Unfree Labour in the Area under German Hegemony, 1930-1945: Some Historical and Methodological Questions", in Brass and Van der Linden, Free and Unfree Labour, pp. I 27-143.

97. Nicolás Sánchez-Albornoz, Cárceles y exilios (Barcelona, 2012), p. I65.

98. Mendiola Gonzalo, "Forced Labor". For construction enterprises see Sánchez-Albornoz, Cárceles y exilios, pp. 165-171; for railways see Mendiola, "Of Firms and Captives".

99. Antonio M. Bernal, "Los beneficiarios del Canal. Latifundios de regadío", in Acosta et al., El Canal de los Presos, pp. xxvii-xxxvi.

Io0. Pastor Ruiz, El Batallón Minero $n^{\mathrm{o}}$ I, p. 74.

ıо . Mendiola Gonzalo, "Forced Labor", p. I97.

I02. Romero, Un deseo apasionado. Leonidas K. Cheliotis, "Punitive Inclusion: A Political Economy of Irregular Migration in the Margins of Europe", European Journal of Criminology (2016, in press). 
maintaining prisons has demonstrated, ${ }^{103}$ and on the other, private, in the search for especially cheap labour. In fact, the administration itself underscores the advantages that prison workshops offer companies, as recently pointed out by the manager of CIRE: ${ }^{104}$ "in many cases we are an alternative to delocalization" of manufacturing to other places with lower wages. ${ }^{\text {Ios }}$ Although in the Spanish case it makes no sense to speak of what has been defined - not without controversy - in the USA as the prison industrial complex, ${ }^{106}$ some trade unions and parliamentary groups are starting to criticize prison work as unfair competition based on dumping. ${ }^{107}$ To conclude, it is even more difficult to estimate the role that might be played in the already mentioned global value chains by the utilization of subcontracting that uses forced labour in the Global South. Such difficulty is due to the illegality of such practices and the company fragmentation within which global production networks move. The implication of Inditex, one of the fastest-growing Spanish companies in recent years, leads me to think that this is not an unusual practice, and the denunciations made in Brazil and Argentina indicate that this practice was well known to company managers. ${ }^{108}$

I03. One of the strategies considered by Wacquant for dealing with the increase in costs inside the prisons: Loïc Wacquant, "Four Strategies to Curb Carceral Costs: On Managing Mass Imprisonment in the United States", Studies in Political Economy, 69 (2002), pp. 19-30, 25-28. LeBaron frames the work of prisoners in terms of present-day accumulation through dispossession: Genevieve LeBaron, "Rethinking Prison Labor: Social Discipline and the State in Historical Perspective”, Working USA. The Journal of Labor E Society, I 5:3 (20I 2), pp. 327-35 I.

I04. CIRE (Centre d'Iniciatives per a la Reinserció / Centre of Initiatives for Inclusion) is the public institution that regulates prison labour in Catalonia.

I05. Antoni López, "Los talleres de las cárceles catalanas facturarán 20 millones este año”, La Vanguardia, I 3 November 2008, available at www.derechopenitenciario.com/noticias/noticia. asp? $i d=1870$, last accessed 22 August 2016. See also Jesús García, "Los presos sustituyen a empleados en los servicios de las cárceles catalanas”, El País, 27 April 2014, available at http://ccaa. elpais.com/ccaa/20I4/04/27/catalunya/I 398623340_7I I633.html, last accessed 22 August 2016. Similarly, in the conservative media COPE, penitentiary workshops have been described as "a national substitute for Asian factories specializing in intensive work"; COPE, "Talleres 'low cost' entre rejas", 3 May 2009, available at http://www.derechopenitenciario.com/noticias/noticia.asp? id $=2293$, last accessed 22 August 2016.

106. For a position critical of this concept, see Loï Wacquant, "Prisoner Reentry as Myth and Ceremony", Dialect Anthropol, 34 (2010), pp. 605-620, 606-6i I. In the USA, LeBaron has documented the effect of captive labour on the free labour market, with a fall in wages and its use during strikes: LeBaron, "Rethinking Prison Labor", pp. 345-347.

107. For trade union complaints: "La Sección Estatal de FSC-CCOO presenta un escrito de queja respecto a la actividad desarrollada por los internos en los talleres de producción con empresas externas", available at http://www.derechopenitenciario.com/noticias/noticia.asp?id $=5622$, last accessed 22 August 2016. In the Spanish Congress, the left-wing Izquierda Plural group presented a proposal that would prohibit enterprises that had previously dismissed workers from concluding labour agreements with prisons. The proposal is available in Boletin Oficial de las Cortes Generales, Congreso de los Diputados. Serie D, 5 I I (2014), pp. I3-I4, available at http://www.congreso.es/ public_oficiales/Lı/CONG/BOCG/D/BOCG-ıo-D-5 r.PDF, last accessed 22 August 2016. ı08. Ana Delicado, "Zara recurre al trabajo esclavo"; Agencia EFE, "Brasil expedienta a Zara". 


\section{CONCLUSION: THE COMPLEMENTARITY OF SUPPLY- AND DEMAND-SIDE APPROACHES}

Throughout these pages we have been able to confirm that in Spain, like in most regions in the world, the development of capitalism did not mean the total triumph of free wage labour; instead, its spread was compatible with the maintenance or creation of modalities of unfree labour.

Taking as a basis the categories established by the Global Collaboratory on the History of Labour Relations, we have been able to see how these modalities show clearly the centrality of the institutional and political framework when it comes to understanding the persistence of forced labour. There is a very evident shift from one period to the next regarding the main categories of unfree labour relations deployed during each of them. First, we must underline the centrality of slavery (category 17 ) for the decades of liberal revolution and colonial empire until i 874. During the next period, that of liberal parliamentarism, labour relations included in category 8 , such as labour taxes for colonial ethnic groups and obligatory work for convicts in African prisons, predominated, with unfree labour being much more important for colonial political and economic control than for the mainland, where unfree labour experienced a clear decline. This reality changed with the civil war and the fascist dictatorship, when political repression enabled the deployment of thousands of prisoners and mostly POWs (category I I). The civil war and its aftermath is precisely the period when forced labour as a proportion of the active population peaked in mainland Spain. Finally, we must remark that during neoliberal globalization unfree labour was found mainly in prisons (category 8 ) and in the form of indentured migration (category is).

Moreover, the research so far suggests that the demand for forced labour was also linked in different ways to the two main reasons identified in the historiography: on the one hand, the relative scarcity of workers, and on the other the pressure to increase profits by cutting labour costs. Nevertheless, historical research has shown that those demand-side factors do not operate in a simple or unilateral way, and that several other elements, such as variations in productivity, level of qualification, living conditions, as well as questions related to the agency of workers (resistance, response to incentives, for example), were essential for explaining why enterprises had recourse to, or rejected, forced labour. Moreover, it is still a challenge for research to be able to determine more precisely the exact contribution of this modality of labour relations to the cycles of capital accumulation and economic growth, as well as the exact proportion of free/unfree labour in different sectors and situations. In addition, one of the main conclusions of this article is that none of these economic factors that help us understand the demand side of forced labour can be correctly understood if we do not also take into account supply-side explanations, those related to public policies. 
We will need more micro-level research in order to better understand the political and economic reasons that explain the survival of unfree labour, not only within historical capitalist development, but also for the disturbing contemporary reality, when unfree labour remains one of the mechanisms underpinning the growing inequality in most parts of the world. 